\title{
China, a Punitive Society?
}

\author{
Børge Bakken
}

Received: 13 March 2010 /Accepted: 10 May 2010 /

Published online: 9 July 2010

C The Author(s) 2010. This article is published with open access at Springerlink.com

\begin{abstract}
The allegation that punishment is a core element of culture does not seem to explain the rapid changes in attitudes towards the death penalty seen in most modern societies during the last few decades. Attitudes of harshness and death in punishment are much more easily changed than proponents of the "cultural" explanation think. The misunderstandings about China (often held by Chinese themselves) are that a long tradition of harsh punishment has made such values into an unavoidable cultural norm. China, however, is not exceptional in harbouring penal populist norms as such, and Chinese history was much more lenient and merciful than assumed in these simplified arguments about "Chinese cultural harshness". Even if China today is exceptional in the uses of harsh punishments and executes more people than the rest of the world combined, there is no need to see this fact in terms of Chinese culture. China can use its own traditions to end this situation effectively in a fairly short period of time if there is the political will to do so. Given such political will, public opinion will follow suit.
\end{abstract}

Keyword China $\cdot$ Punishment $\cdot$ Culture $\cdot$ Death penalty $\cdot$ Mercy

\section{The Chinese Regime of Harsh Punishment}

It has been argued that punishment is a core element of a culture, and one of the catchphrases of criminological textbooks was indeed that "we learn to react punitively... just as we learn to speak a language" (Sutherland et al. 1992: 328). In other words, it was held that punitive norms constituted some of the strongest marks of culture. I think this assumption is less than accurate, and that punitive norms are much less likely to prevail than your mother tongue, but we find similar views in present day Chinese discourses on punishment. In a recently published anthology on the uses of the death penalty in China, Professor Gao Mingxuan argues that: "(for) historical and practical reasons, the retributive concept is deeply rooted among the citizens (of China)", and he goes on to argue that the

B. Bakken $(\bowtie)$

University of Hong Kong, Room 1208, 12/F, K.K. Leung Building,

Pokfulam Road, Hong Kong, Hong Kong SAR

e-mail: bakken@hku.hk 
consequences of such deeply rooted punitive preferences is that "China will not abolish (the) death penalty at present or in the near future" (Gao 2004: 19,29). I will not discuss here when or whether or not China will abolish the death penalty, but rather question the assumption of deeply rooted popular sentiments as an argument for upholding a punitive sanctioning system. My topic also is not the death penalty as such, but more the assumptions of a punitive culture of which the death penalty is a very important indicator. I think we have to look in directions other than those advocated by Sutherland and, to a lesser degree, Gao on this account. One alternative can be found in legal institutional historical research about the occurrence of legal mercy in the judicial system.

Émile Durkheim formulated one of the most potent hypotheses of the link between modernity and punitivity, assuming that modernity gradually would lead to a less punitive sanctioning regime. More specifically, he declared that punishment, in the form of penal or repressive law, is supposed to decline with industrialization and modern division of labour-so-called organic solidarity (Durkheim 1983:19). Reading present Chinese discourses on that matter, many scholars seem to agree with the general truth in that assumption, and I will come back to indications supporting that it is later. There are, however, certain problems with this assumption. For instance, the United States seems to follow quite another path than most European nations in this regard, and both practices and attitudes seem to be highly punitive in the US, which is one of the last developed countries (together with Japan) to keep the death penalty (although many individual American States have abolished it).

A potent attempt at explaining why the United States has ended up in a much more punitive position than Europe can be found in studies of history and historical sociology concerned with the legal traditions and various forms of punishment cultures experienced in different nations. James Whitman has argued recently that the striking differences between Europe and America in this regard are due to fundamentally different traditions in legal institutions and legal thinking (Whitman 2003). The basic argument here is one of how to look at social status and social hierarchies. In Europe, a general commitment to abolish harsh low-status treatment developed gradually. In the young settler state of America, where status hierarchies were much less pronounced, it seems as if the milder punishments used for the aristocracy in Europe never gained ground, and everyone got the same harsh punishments in the name of equality. Harsh punishment was in fact seen as a virtue of equality in America-indeed, we find something we might term "violent egalitarianism" there. It is one of the paradoxes and unintended consequences of history that the milder high status treatment existing in the otherwise brutal ancien régimes of France and Germany was generalised to the common people, particularly after the French revolution. Here, mildness in punishment was advocated as the ideal of equality instead of the violent popular egalitarianism of America. The French and the American revolutions, although built on the same basic ideas of egalitarianism and freedom, had very different outcomes in terms of legal practices. In other words, while high status punishments have slowly driven out the low-status treatment in Europe, harsh punishment became the ideal during the American Revolution, a revolution, I might add, more fanned by populism and puritan Christianity than its European counterpart. But even enlightenment itself is partly to blame for the harshness seen in America. European enlightenment, we should remember, was not only the writings of Beccaria, who suggested the abolishment of the death penalty already in 1764 (Beccaria 1764/1996). It was also the Kantian harshness of act egalitarianism, the principle that everyone should be treated equally and, I should add, equally harshly. The purity argument, however, is still important here, as purity also seems to lead to harshness in sentencing. I will merely mention that topic here although it deserves more thorough 
discussion. Mary Douglas argued that ideas of purity and pollution strengthened the demand for active human punishment (Douglas 1966, p.134). Among other examples of what I would call "purity regimes", the Chinese Cultural Revolution is a good example where punitivity and purity go hand in hand. We just have to think back to the so-called "Gang of Four" who flirted openly with old and very punitive legalist ideas during the late days of the Cultural Revolution, trying to link feudal ideas of the absolute monarchy of Qin Shi Huangdi to the socialist revolution of Mao Zedong. It is also significant to note that the anti-crime campaign of 1983 started in an atmosphere of a political campaign against spiritual pollution (jingshen wuran 精神污染) that saw crime as a pollution factor, or a phenomenon of evil. I will come back to such phenomena and their effect on punishment later, but such ideas of purity and pollution seem to trigger a violent and punitive reaction in general.

If we look more closely at developments in Europe, we have to understand that values of mercy were much more pronounced in Europe than in America. We also have to search for reasons why it was so much stronger in Europe. Again, part of that answer can be found in the argument of status-hierarchies. Mercy comes de haut en bas as they say in France, from up to down. In some fundamental way, it seems, one has to have the social distinction of high and low to be able to develop mercy. To develop this argument, we also have to incorporate ideas from the historical school based on the works of Norbert Elias. It has been found that a relatively strong nation state with a relatively strong and autonomous state apparatus was able to contain violence and unrest in medieval Europe. Violence rates seemed to be much higher when the state was weak and revenge cycles were allowed to rule in the absence of strong institutions of social control (Johnson and Monkkonen 1996; Elias 1994). It can be argued that in America, the widespread skepticism against a strong state is among the explanations why violence and punitivity came to reach higher levels there than in Europe, and we might see part of today's more violent American culture as a byproduct of both the lack of institutions of mercy and the lack of a strong state. Only a strong state, I argue, could actually grant mercy to the people on a large scale. I cannot do justice to a long and complicated argument by this sketchy description of the differences between Europe and America, but I can arrive at one of the basic points of the argument.

The historical use of legal traditions of mercy can explain present regimes of punitive sanctions in different countries on a more institutional basis, and we do not have to rely on a more reductionist argument about the inevitability of deeply rooted "cultures" of punitive sentiments among the people to understand the causes of today's justice systems. The culture of punitiveness is learned in a historical and political context, and this context is much easier to manipulate, particularly by strong states, than the alleged inertia of deeply rooted popular cultural elements. On the other hand it is also easy to manipulate and feed populist sentiments for reasons of legitimacy and power.

There is, however, some substance in the argument that cultural differences in sentiments have historical significance also in terms of institutional change. I have much respect for Pieter Spierenburg's approach when he argues that the intensity of emotions (and thereby the use of cruelty and violence) during the medieval period in Europe was "tamed" or contained by the introduction of the nation state, and that the acceptance of "blood sacrifice" and violence decreased over the centuries, while sensibilities about suffering increased (Spierenburg 1984). Sensibilities can be extended to peoples' tolerance towards violence, as can be seen in the ways they look at punishments. The nation state had a civilizing effect in expropriating the revenge of the masses, gradually containing that revenge in a legal code. This approach has been supported by rich empirical evidence, and has been utilised to explain developments in crime, violence and punishment in medieval 
and early modern Europe (Johnson and Monkkonen 1996). Sensibilities have to do with the general experience of modernity, but Spierenburg cautions us not to interpret the development of sensibilities too mechanically. After all, public decapitation by the guillotine continued in France until the late 1930s. Rather than seeing sensibilities as a clear-cut linear perspective, Spierenburg argues that sensibilities are in permanent tension. In China, the historical situation might have been different, although we find the same tension there as in European history. Nevertheless, although formally illegal according to Chinese law, torture is still rampant within the Chinese public security apparatus, and the death penalty and its practice seem to be widely accepted in China today despite the country's leap into modernity. This strong belief in harsh punishment in the face of modernity might seem puzzling.

The Chinese imperial regimes had their share of brutal means of execution and punishment, among them death by slicing (lingchi 凌迟) where the alleged perpetrator's body was dismembered piece by piece. The theme of insult and humiliation was strong, and seen as part of the punishment. In the case of chuo, (翟) poking or stabbing, the corpse was stabbed so as to insult the deceased (Chen 2000: 115-16). While different forms of capital punishment was an integrated part of the criminal justice system at least from as far back as the Qin dynasty (221-207 BC), its use appears to have been less frequent than might be assumed (Bodde and Morris 1967: 141-42). Beyond the harshness and rigidity, there existed a surprising degree of mercy, compassion and flexibility. The Chinese imperial tradition was by no means harsher than the regime of executions and punishments practiced in Europe at the same time. Some analysts have maintained that the Chinese system was in fact less harsh than its European counterparts, where extreme tortures and tormented executions were regularly practiced and often found a religious justification. Because this abolishment of bodily pain as a method of punishment occurred earlier in Europe than in China, during the late days of the Qing dynasty, Imperial China came to be seen as the gruesome man of the orient in Western conceptions. In particular, German pictures of the last slicing in 1908 reached a shocked European public and cemented the Western picture of the "gruesome Chinaman" (Bourgon 2003). There is no need, however, to elevate the cruelty of the late Qing dynasty into "Chinese culture" as such, and defend such misinterpreted "Chinese culture" with attacks on an equally esoteric "Western culture" whatever that expression means. American? French? German? Scandinavian? Such culturalist arguments are scholarly weak, often based on anecdotes and unclear assumptions about "national psychology", and are better used for nationalist and ideological agendas. Such arguments in fact have little to do with a scholarly discussion of what causes harshness and death in bureaucratic punishment regimes. Arguments of power, politics, and order are here concealed under the cloak of hard-to-grasp "cultural psychology". Even so, otherwise informed and enlightened Chinese legal scholars leave their fields, and their often stringent analyses, to return to such murky arguments as the "social psychology of the Chinese nation", assuming there are more or less direct links between such alleged deep cultural psychology and concrete policy implementation and legal structures (Chen 2003). Paradoxically, this alleged "cultural" defence or legitimisation of Chinese death penalty practices today functions more like a "talking down" on Chinese culture than as a defence of the roots of that culture. Internationally, the argument today functions more like a reinvention of the misconceived and hundreds of years old "gruesome Chinaman". Although feudal states all had their share of cruel punishments, and even though the Chinese, like most nations, have had their fill of popular revenge culture (Madsen 1990), Chinese culture, whether popular nor official, was never primarily about revenge and cruelty, death and destruction. Such elements were in fact weaker in China than in almost 
any other civilization at the time, and the Tang dynasty even saw a short period (from 747 to 759 AD) where the death penalty was abolished (Benn 2002, 209-12). A recent book on Chinese penal history succinctly sums up the point of relative leniency and balanced regulation:

\begin{abstract}
"When compared to the execution of corporal punishments in early modern Europe, what stands out in the Chinese case is not only the concern that punishments should be inflicted correctly, but also the government's reluctance to stage executions in the elaborate way that was common, for instance, in France, Germany, and Great Britain... (The) executions in late imperial China were no match for the ferocious events staged in eighteenth-century Europe". The author concludes: "The punishments carried out in imperial China were largely reversible and relatively bloodless, marked by the intention to carefully refine and graduate the use of state violence" (Mühlhahn 2009: 40, 54).
\end{abstract}

The Confucian pan-moralist tradition might, instead of cruelty and harshness, have represented a civilising effect in this cultural regard since it advocated a form of legal humanism in contrast to the tradition of harsh punishment. Confucianism was challenged by the other strong influence in Chinese legal thinking, the legalist school (fajia 法家). Harshness in sentencing was the core of their legal system, and only extreme brutality and horrible torture would subsequently end all punishments, according to their preMachiavellian political philosophy. There is a historical link here, but today's harshness cannot be explained by mere historical analogy. Let us then go back to the argument of legal mercy and the effect it has towards a milder sentencing regime. Instead of talking about an alleged "Western culture" in terms of institutions of mercy, we should rather ask the question of whether imperial China was more like Europe or more like the United States? China was a strong state with a clearly pronounced status-hierarchy, and the practice of $b a y i$ (the eight considerations) resembled the old European system of high-status punishment. There were prescribed regulations granting special judicial procedures to eight different groups of people. The term originated as early as during the Zhou dynasty, entered law as early as the Wei dynasty (220-265 AD), and remained in all subsequent codes. Among the eight groups were members of the imperial family, descendants from former emperors, and high officials, the mandarins and their families, as well as various "persons of great merit". Even if the system varied in form from dynasty to dynasty, such persons could not be arrested, investigated, or tortured without direct permission from the emperor, and their punishment would be milder than that meted out to people of lower classes, although we also find cases where officials actually got harsher punishment because they were seen to be models for the common people. Of course this was a feudal, class-based form of legal procedure but, at the same time, this system of status-hierarchy laid the groundwork for another type of institution, that of legal mercy. The answer to the question of whether imperial China practiced mercy or not is that China had one of the most developed institutions of legal mercy that the world has ever known.

\title{
Mercy in Chinese Legal Tradition
}

It has been argued that the tone of a civilization can be found in its treatment of deviants. Fortunately, the rich Chinese records of traditional Chinese law codes recount thousands of instances of the amnestying of criminals and the extent with which legal mercy was practiced. General amnesties and acts of grace or mercy were granted frequently. In his 
illuminating book of the practices of legal mercy, Brian E. McKnight has translated the Chinese expression she (赦) as “acts of grace" when used as a noun, or as “amnesty” when used as a verb (McKnight. 1981: xi). I prefer the expression of legal mercy here. The most extensive forms of grace or mercy were called dashe (大赦)—great acts of grace or mercy. These general amnesties applied to the whole empire and were conducted with much ritual pomp and circumstance. At least from the Han onwards this practice was used extensively. Dashe was not the only form of mercy being used, and the methods and frequency of the use of mercy differs throughout the imperial period. While ordinary amnesties merely reduced their penalties, the great acts of mercy forgave the offenders entirely. It is not necessary in this short discussion to give a more extensive explanation of the different forms of mercy, it will be enough to point to the existence of an extremely strong Chinese legal culture of mercy to establish the argument of a legal history favouring milder punishment rather than harsher sanctions.

There have been attempts to estimate the frequency of the use of mercy in traditional China, and the findings are stunning. From the founding of the Qin dynasty in 280 to the fall of the Tang in 907, a great act of mercy was issued on the average of once every 18 months. The remarkable system of legal mercy reached its peak during the Song dynasty and, in terms of frequency, the average pattern of the former period was upheld throughout its entire rule both through Northern Sung and Southern Song (960-1279). Executions must have been reduced extensively by the use of this system, and the harshness of the black letter of the law was reduced significantly by the frequent practices of legal mercy. Some dynasties used legal mercy less frequently than others, but all dynasties upheld the tradition to one extent or other. Even during the Qing executions were often suspended, and the system of legal mercy did not disappear before the empire disappeared. This is not to say that the imperial order was not an extremely harsh order, and there is no need to underestimate the harshness and brutality of the imperial regime in general. We could hardly expect a feudal aristocracy to be much different. Some of the empires were formed only after protracted military struggles, and we know from modern criminological research that such incidents of war and military strife represent an increased harshness reflected in their judicial systems.

The legalist school attacked the legal use of kindness and benevolence in principle because, in their view, such benevolence could in fact foster unrest and lawlessness rather than harmony and lawfulness. Their belief in the positive effects of deterrence was enormous. Deterrence was always a goal of punishment in traditional China as it was in medieval Europe, but China had more elaborate methods to supplement such deterrence by benevolence. The introduction and extensive use of mercy in traditional Chinese law had lasting implications for the feel and tone of Chinese justice in general, and it is this tone that has got lost along the way to a modern society. If the argument about the effect of institutions of legal mercy on the punishment regime is correct, China has all the required potential to develop a far more lenient and far less punitive system of justice than now seems to be the case. If the European tradition of status-hierarchy and the use of legal mercy had the effect of reducing the harshness of their justice system, China should have this opportunity in abundance. In other words, not only does China have the necessary ingredients for the milder sentencing found in continental Europe, it surpasses the European conditions and can boast a system of mercy without precedence elsewhere in the world.

As for the populist argument about the anger of the masses, historical revenge cycles existed in Europe as well as in China, and the deep roots of retribution in Europe should not be significantly different from those in China. It is not that popular revenge is not a problem in today's China, since there is still fresh evidence in China of such popular revenge (Zhu 
2003, 2,3). We need, however, far better research to be able to point out that this is a more serious problem in China than it is in Europe. Popular revenge was gradually more and more contained in Europe, and the nation state worked effectively against popular revenge rather than to support it. In Maoist China, as we shall see later, an official support for popular revenge rather than an expropriation or containment developed . During times of crisis, however, such as the breakup of former Yugoslavia in the 1990s, violent revenge cycles bounced back even in Europe. Since popular revenge seems to exist all over the world to a greater or lesser degree, we should instead focus on the matter of political will when we look at popular support of harshness in punishment in general and the death penalty in particular.

According to the United Nations, global data shows a clear connection between people's conceptions of punishment and the practices of the regime (Newman 1999). Where regimes opt for harsh methods of punishment, the people will follow by supporting harsh punishment. If the regime introduces milder forms of punishment, people's attitudes will follow and turn milder. This trend seems to be without exception, although the degree might vary from country to country. Few Chinese scholars put emphasis on the lack of official political will to abolish the death penalty because it is a sensitive area to write about. Although not directly addressing abolition, still some scholars have commendably addressed the issue of political will (zhengzhi yizhi 政知意志) as contrasted to the often irrational and emotional popular outbursts linked to the death penalty. In an argument about avoiding the excesses of public indignation or revenge, Liang Genlin argues for rational political guidance or leadership (yindao 引导) combined with the political will to reform the death penalty regime, and warns against the potentially hysterical and collectively unconscious feelings linked to the issue of so-called popular indignation. While the authorities should listen to public opinion (minyi 民意), he argues, they should be cautious about basing their arguments on emotional public indignation (minfen 民愤) (Liang 2004: 15-27). Liang has started an interesting discussion, but might also have warned the authorities against the historical misconceptions that often form arguments of cultural-historical support for the death penalty. The authorities could have looked back to their own history of mercy for arguments against the death penalty instead of exaggerating the emphasis on popular revenge culture. Again, the question of whether to retain or abolish the death penalty is not so much about culture and psychology as it is about power, politics, and political will.

The paradox, however, is that the elaborate and extensive use of mercy in traditional China does not seem to have developed into a general approach of milder sentencing in modernity. My argument here is that I still think the historical potential for mercy and a milder sentencing regime exists in abundance in China today, and that it is quite wrong to blame Chinese culture and the alleged deeply rooted retributive sentiments of the Chinese people for the present harsh punishment regime. The granting of mercy, however, was also a political question. The emperor granted mercy from the position of strength, and mercy was given to underline the power of the emperor. We may look at that harshness of punitive reactions in a more political and much shorter time perspective. The historical challenge to the old class-based system, Marxism, once represented another potential humanizing factor, since the communists looked at the death penalty as a cruel method that should be abolished. More precisely, on 15 June 1922, the Chinese Communist Party formally suggested that the death penalty should be abandoned (Zhao 2004, 11,18). In the period of war and revolution, this position was abandoned; the attack on the communist movement by the Guomindang in 1927 might explain some of that reaction while the realities of war and revolution must be blamed for the rest. Before the Cultural Revolution, however, in his political report to the Eight Party Congress in 1956, premier Liu Shaoqi spoke on behalf of 
the Party when he again advocated the future abolition of the death penalty (Leng 1967, $50-51,167)$. Likewise, legal textbooks from the 1950s saw the death penalty in the picture of "gradual abolishment", and stressed the necessity to apply the punishment to a minimum of cases only. Thought reform and rehabilitation together with prevention were seen as far more viable methods. Although the death penalty was frowned upon in Chinese Marxist discourse, the regime has always resorted to the use of it, all the time claiming that it is necessary "at this stage of development". The present talk about "gradual abolishment" follows this tradition (Zhao 2007).

Even more important, Mao Zedong was firmly against expropriating the violence of the masses, and he saw capital punishment as a tool to be used against counterrevolutionaries. The death penalty should be used with caution, and only in a limited number of cases, against "the worst local tyrants and evil gentry" (Mao 1927/1967: 38). Mao, however, advocated that the people should have the right to take revenge against their exploiters. He refuted the argument that peasants had "gone too far", and supported the killing of landlords, claiming that "it is necessary to create terror for a while in every rural area" to be able to fight the rule of the landlords (Mao 1927/1967: 29). Mao saw execution as justified on the grounds of retribution to appease the masses. In the later campaigns against counterrevolutionary landlords, he repeatedly called for the worst counterrevolutionary perpetrators to be executed "so as to assuage the people's anger" (Mao 1977: 56). Even his later Cultural Revolution could be seen as the non-expropriated violence of the masses. The Maoist argument about appeasing the people's anger or indignation一minfen 民愤—seems to have developed into a basic legal principle that still lingers on in Chinese legal thinking. The people's anger replaced notions of mercy (renci 仁慈). Mercy instead found its negative way into the modern vocabulary in the slogan: "To show mercy to the enemy is to show cruelty to the masses" (dui diren renci jiu she dui renmin canren 对敌人仁慈就是对人民残忍).

Instead of mercy from up to down, the class struggle of the revolutionary period defined the situation as one of a struggle between the friends and enemies of the people. The first line of the first volume of Mao Zedong's selected works indeed makes the friend-enemy dichotomy the basic question for the whole revolution: "Who are our enemies, who are our friends? This is a question of the first importance for the revolution" (Mao 1927/1967:13). While this was the strategy of revolution, in legal terms in a more peaceful period of development, this principle could be compared to the historical development from looking at crime and deviance as mala in se, as evil acts, as against the principle of mala prohibita - acts merely prohibited by the state. While in the revolutionary period one was looking for enemies and evil, in legal terms one would expect a developing and modernising nation to focus less on "counter-revolutionary crime" and more and more on "normal" or "traditional" criminal behaviour. In other words, modernity would mean to adopt the principle of mala prohibita rather than mala in se. This was the general historical development seen in Europe. What happened in the People's Republic of China?

The populist principle of minfen did not cease to exist with the end of the revolutionary period. For instance, a report on rural hooligan gangs (tuliuzi 土溜子) during the period of modernisation concluded: "a few of the most evil among them should be resolutely executed to avoid the indignation of the common people" (Xu 1988: 157). This attitude also developed into the dominating rationale for the anti-crime campaigns, starting in 1983 (Tanner 1999). There is also much public support in China for harsh sentencing and the use of the death penalty, and this support at first sight seems to support the cultural argument on the necessity of harsh punishment.

Deng Xiaoping had a golden opportunity to change all this when he came to power in late 1978. Instead of a less draconian regime of punishment, we have seen a substantial 
increase in the use of capital punishment since the death of Mao in 1976. The number of executions probably tripled during the first 8 years after the onset of economic and legal reforms in 1978 (Scobell 1990). Deng's firm belief in the preventive effects of harsh punishment, however, challenges early Marxist viewpoints held in China, as well as going against strong evidence in criminological research summed up by one of the world's leading sentencing scholars, Andrew Ashworth: "[I]f criminal justice policy expects sentencing to perform a major preventive function, it is looking in the wrong direction" (Ashworth 2000: 25). Even Chinese scholars now admit that: "you cannot prove its [the death penalty's] effectiveness" (Reuters News 2004). Ever since the reform started in the late 1970s, the yanli (严厉) or harshness of sentencing, and the yanda, (严打) the "hard strikes" against crime have dominated the penal credo in China (Trevaskes 2007). Harshness in itself has become the core of the argument in criminal justice policy.

Harshness was elevated to a basic principle of punishment when China opened up for legal reforms in the late 1970s. The crime situation in China in 1981, before the launch of the "hard strike" campaigns 2 years later was described in the alarmist manner of the fear of crime. It was said that: "good people fear bad people, but bad people do not fear good people" (haoren pa huairen, huiren bu pa haoren 好人怕坏人, 坏人不怕好人) and "those who enforce the law fear those who break the law, while those who violate the law do not fear the law.” (zhifa de pa weifa, fanfa de bu pa fa 执法的怕违法, 犯法的不怕法). In this situation, Deng Xiaoping saw execution as an "indispensable means" through which the masses could be educated (Zhou et al. 1981: 5). Instead of advocating a more lenient use of the death penalty after years of brutalisation and extra-legal executions during the Cultural Revolution, Deng accused the reconstructed courts of being "too soft on criminals". Deng called directly for greater use of the death penalty, and advocated extending its use to cases involving major theft, corruption, recidivism, and a range of crimes where it had not been readily used in the past. He also advocated the death penalty for those who "prey on people's superstitions", and those who "organize reactionary secret societies" (Deng 1987: 137). Today nearly 70 types of crime carry the death penalty, in practice there may even be more. Of course the level of official brutality was far less during Deng than during the heyday of Maoist extra-legal excess, but in terms of legal executions, there was a clear increase from the late 1970s to the mid-1980s and onwards. Dengist reform tightened the screw of punishment.

For Deng it was important to root out the ills of economic crime by "constant and protracted struggle" against what he called the "ill winds" of economic crime and corruption. He saw such crimes as a challenge to his entire modernisation program and the power of the Party. He advocated "prompt, strict and stern measures", and advocated that the "ultimate penalty" must be used against the perpetrators. He even added to his comrades whom he repeatedly held to be "too soft" that: "this is not just alarmist talk" (Deng 1984: 381).

While most of the criminals sentenced to death over the last two decades or so have been convicted of what would be considered extremely serious crimes everywhere, some have been found guilty of petty crimes like car-theft, grave-robbery, purse-snatching, petty theft, and - in one famous incident - pinching the buttocks of women. In particular recidivists have been put to death over lesser offences. Although the executions now took place in a new and legal framework, the harshness of the system did not disappear. Perhaps it is accurate to describe the differences in Mao's and Deng's legal ideas with the Chinese expressions of guangchanghua, 广场化 (justice in the public square) as opposed to juchanghua (剧场化) (justice in the theatre, or the courtroom). While Mao stood for the first approach, Deng advocated the latter. Where Mao was a traditional populist believing in retaining the people's rights to retaliate, Deng was "modern" only in the sense that he 
wanted a much stronger state apparatus to expropriate the people's revenge. Harshness, however, remained both in Mao's public square and in Deng's court theatre.

Deterrence and the "harshness" of punishment were held to be the most fundamental special characteristics of the Chinese anti-crime campaigns. There is still a touch of the old belief that socialism can eradicate crime, rather than merely reduce it. One current slogan went like this: "Only by being severe can we cure crime for good." The classical theme of parading defeated vice have remained in vogue in China. The practice of holding public sentencing rallies is still common. Today such practices would be seen as humiliating to the offender in European legislation. In China it is still seen as an educative display. The authorities aim not only to show who is in control, but also to make the streets safer for the public, particularly during holidays and festivals. It is called "killing the chicken to scare the monkey", assuming a successful deterrent effect. Criminology has established that the monkey does not stay scared for long. The method might be effective over the short term, but deterrence does not work over the long term (Phillips 1980; Bailey and Peterson 1989; Stack 1987). The authorities, however, continued to mete out death penalties for an increasing number of crimes (Survey of World Broadcast $1992^{1}$ ). This might reflect a fear of crime triggered by the moral panics that often haunt transitional societies. Moral panics constitute the climate necessary for what has been termed "penal populism". As has been shown in Western countries, penal populism can be politically useful, but has nothing to do with penal effectiveness (Roberts et al. 2003). In China, the popularity of the harsh anticrime campaigns have been used as a means for the regime to gain support in an insecure environment of transition. Harsh punishment proves the point to the public that the government "is doing something" about the negative consequences of economic reforms. The alleged positive net effect on the crime rate, however, is of a more dubious character, and it is less than likely that the campaigns managed to reduce crime.

I do not doubt the argument that penal populism about retribution still has a strong foothold in China, and harsh treatment of criminals does enjoy considerable public support. A Public Security Ministry survey of 15,000 people showed that the vast majority thought the state's handling of criminals was either just adequate or not tough enough. Nearly $60 \%$ of the respondents answered that they found the existing laws "too lenient". Only $2 \%$ found the laws "too strict" (Zhonghua renmin gongheguo 1992: 46, 60, $250 \mathrm{ff}$ ). It is important to note that popular support for harsh punishment is a common phenomenon in most societies (Stalans 2003). However, such attitudes might not reflect an inevitable "will of the masses" and, contrary to popular belief, can sometimes be fairly easily changed by state intervention. In a survey among 2000 persons in China in 2005, the respondents were asked if they supported the death penalty or if they wanted it to be abolished: $82.1 \%$ supported it, while $13.7 \%$ said they wanted it abolished. When the question was changed, and rephrased on the assumption that the death penalty had already been abolished by the state, only $60.6 \%$ wanted to retain the death penalty, while the number of abolitionists had increased to 33\% (Zhao 2005: 226). Support for the death penalty was now considerably lower than it is in public surveys in the United States. So much for the argument of the

\footnotetext{
${ }^{1}$ On a special "anti-drug day" in Yunnan in October 1991 as many as 88 people were sentenced to death for drug dealing in 14 different prefectures. See $S W B-F E / 1215,29$ October 1991, p. B2/1. On death penalties for embezzling, see $S W B-F E / 1187,26$ September 1991, p. B2/4. One criminal, released after a prison term, was executed after he helped steal two cars. $S W B-F E / 1193,3$ October 1991, p.B2/8. On grave robbers executed in Changsha, see $S W B-F E / 1419,29$ June 1992, p. B2/4. A man who stole state power equipment was sentenced to death in Harbin, $S W B-F E / 1189,28$ September 1991, p. B2/4. In Xian two thieves from Shaanxi were executed after several incidents of theft averaging slightly over 1,000 yuan (or less than US\$200), and for stealing 25 tons of grain, $S W B-F E / 1158,23$ August 1991, p. B2/5.
} 
"culture of death penalty" in China. This survey shows what we already know from death penalty opinion research in other countries, that if the state passes legislation banning the use of the death penalty, public opinion will instantly follow suit. For our purposes it is enough to conclude that there are no fixed and culturally strong incentives that force Chinese opinion to routinely support the death penalty. The death penalty has until recently been a kind of taken-for-granted truism in China, and this situation is now about to change.

The International Crime Victimization Survey (ICVS) included an analysis of crossnational attitudes to punishment that seems to confirm remarkably strong Chinese punitive attitudes. People were asked to evaluate a case where a 21-year-old man had stolen a colour $\mathrm{TV}$, and is found guilty for the second time. The alternatives ranged from imprisonment, to community service, suspended sentence, a fine, or other reactions. With the United States as one notable exception, people in industrialised nations were most likely to choose community service. The developing nations were all strongly in favour of imprisonment. Of 58 nations, China came out as the most punitive of all. As many as $84 \%$ of Chinese respondents wanted imprisonment, followed by Uganda (80\%) and Zimbabwe (79\%). Only $7 \%$ of Spanish respondents (Catalonia) wanted imprisonment, while $56 \%$ of Americans did. When people who were in favour of imprisonment were asked to decide the suitable length of the sentence, Tanzania was the most punitive of the nations, with a suggested average of 87 months, followed by Botswana (75), Cambodia (61) and China with a suggested 51 months of imprisonment. Only $2 \%$ of Chinese suggested a fine as punishment, and among the 4\% suggesting "other reactions", even the death penalty was included. In the Chinese survey, men were found to be slightly less punitive than females (Mayhew and van Kesteren 2003). China seems to be in strange company with a lot of punitive developing nations from Africa and Asia. This does not point in the direction of modernity. On the contrary, this punitive party is made up of some of the least modern, least advanced, and least developed nations in the world. China - a nation that is closing the gap to other developed nations in nearly all other areas - should reflect thoroughly on this phenomenon.

Paradoxically, within the police force, anti-crime campaigns are not popular. Numerous police officials have criticised the tendency to turn these "special struggles" into a routine, almost constant, state of affairs. Police personnel are worn out by constant campaigning. Even criminals know when the campaign is turned on, choosing their strategies from that knowledge. Many feel that professional policing suffers from the approach. The campaigns do not reduce crime, instead they brutalise the crime scene, making the job of the police even more dangerous. This brutalisation finds a chilling but effective measure in the number of policemen killed on duty since the founding of the People's Republic of China. During the 31 years from 1949 to 1980 , the official number of police officers killed was 1,026. In the 17 years from 1981 until 1998 the number was an additional 4,800, and if we follow the trends since then we find that close to 6,500 police officers were killed on duty during the last 20 years (Feng 2001:125). In 2001, 443 police officers were killed on duty, and the high death rate is, according to police sources "reflecting the increasing number of violent crime" (BBC Monitoring 2002). While it must be added that many police also die in accidents, the general trend of brutalisation as an effect of capital punishment has long been pointed out by criminologists (Bakken 2000, 397, Bowers and Pierce 1980; Cochran et al. 1994; Reuters News 2004; Shepherd 2005). The critique of death penalty abuses in campaign-style policing has also begun to show signs of gaining a foothold in Chinese legal circles. There are more and more people in the legal sector who hold that faith in increased severity of punishments is unproductive as well as unscientific, while fewer see the disruptive effects of the death penalty. Chinese scholars themselves have, however, reported the same effects of brutalisation that we know from international research. Contrary to 
showing any deterrence effect, international research on executions have shown a predicted brutalisation effect on the level of stranger homicides (Cochran et al. 2000). Stranger homicide, or killings where the victim does not know the offender are relatively rareunder $10 \%$ of the total number of homicides in most European countries for instance. Without going into too much detail here, suffice it to say that the predicted effect of high levels of stranger homicide has been found in abundance in China recently, with shocking stranger homicide rates for cities like Beijing (50\%) and Shenzhen (53\%). Even smaller cities like Huhehot in Inner Mongolia show stranger homicide rates on or above the level of large American cities (nearly 20\%; Zhao 2006). These are alarming data for those who believe in the alleged deterrent blessings of "hard strikes" as executions spur some offenders into committing more violent crime. This trend tends to exactly oppose what is needed for a "harmonious society", and the brutalisation is socially disruptive. Evidence for general brutalisation following the use of the death penalty has been found even in crossnational studies (Archer and Gartner 1984).

There have been campaigns against police brutality in China recently, and there is a serious effort to modernise the police force in terms of education and equipment as well as attitudes and accountability. Today, however, there are still numerous deaths in custody, and people killed in police operations. American figures clearly show that the ratio of citizens to police killed in deadly encounters leave the public as victims far more often than police. American figures indicate a ratio in the order of 5:1 (Kobler 1980). The Chinese figures are unknown. There are, however, initiatives from the top leadership who now seem to go against a campaign style policing in crime control, and it seems the time of the great anticrime campaigns may be over, at least on the central political level. Locally, however, the yanda campaign still seems to live on in some form or other.

China continues to regard statistics on the death penalty as a "state secret" even if internationally accepted instruments requiring all countries still using the death penalty to publish statistics on its use, so we do not yet know the exact number. It is clear, however, that, even by low estimates, Chinese execution numbers today exceed by far the number of legal executions recorded in the rest of the world combined. I will not speculate here on the accurate number of executions in China today, suffice it to say that the current official Chinese reaction is that the execution rates in China are "too high" (Lim 2004).

Most Chinese have a deep-rooted fear of lawlessness and chaos (luan 乱). There is strong support for a government that maintains law and order and forcefully metes out severe punishment to those who break the law. A survey on attitudes towards the death penalty among more than 5,000 respondents, conducted by the Institute of Law at the Chinese Academy of Social Sciences in Beijing in 1995, reveals interesting data about popular sentiments in China (Hu 2000: 341-46). The survey suggests extremely high support for the death penalty. The United States is known for its strong support of harsh punishment in general, and the American population's support for capital punishment is very high by international standards. Data from the US, provided by the Field Institute, shows a support rate of $68 \% ; 26 \%$ were opposed, and $6 \%$ had no opinion (Kataoka 2004). The Chinese survey shows much higher support rates for capital punishment. Overall, less than $0.8 \%$ wanted this type of punishment abolished. The rest, more than $99.2 \%$, supported the death penalty to a greater or lesser degree. Only $3 \%$ among these supporters wanted the use of the death penalty reduced, while nearly one-quarter of the respondents wanted to see it used more often. Among the interesting observations in this survey is that there is no significant difference in attitudes between men and women, that the urban-rural divide does not show significant differences, and, quite surprisingly, that people with the highest education were more likely than those with less education to support capital punishment. 
None of the respondents working in the judicial sector supported abolishment, although they were the least likely supporters of more frequent use. The military personnel group of respondents was by far the most avid supporters of capital punishment, with nearly $43 \%$ supporting even more death sentences. Illiterates and some minority people (in particular the Dai in Yunnan) were most likely to oppose the death penalty. Significant is also the fact that the richest people were more likely to support abolishment. In the latter group, less than $6 \%$ advocated more use of the death penalty. More than $30 \%$ of those with the highest education wanted even more frequent use of capital punishment. In the United States, lower class black respondents are the most likely supporters of abolishment. They are also the group most readily targeted by the death penalty. In China, the Yunnanese minorities are more likely to be targeted in connection with drug trafficking over the southern borders, illiterates are often found among vagrants and migrants frequently targeted by public security, and the nouveau riches are cautious since they are easily targeted for shady business deals in a maverick market. It is, however, highly unusual to see the highest educated group as the most eager supporters of capital punishment. In international surveys they are usually the group least likely to support this kind of punishment.

One example where the most highly educated elite was also the social group most likely to favour the death penalty, is pre-war and war-time Nazi Germany (Reuband 1980). The Nazi elite's support for this aspect of fascist state ideology was a sign of their elite status. Such support for capital punishment among the highly educated elite in today's China reflects the fact that this punishment has often become synonymous with order and stability in state and party propaganda. Support for the death penalty may seem to be part of an elite ideology, something signifying the "quality" of one's elite status. This support also reflects a fear of what Europe used to call the "dangerous classes".

The positive experience learnt from the German example, however, is that changes in attitudes towards the death penalty are highly dependent on the state's own practices of punishment. With changed policies in post-war Germany, the massive support for capital punishment was turned into support for its abolishment. The post-war German constitution banned capital punishment, and support for the death penalty sank from $80 \%$ to $44 \%$ of the population in only the 16 years from 1958 to 1974 . Today, support in Germany for the death penalty in general is $34 \%$ (only $14 \%$ are "strongly in favour"). As punishment for murder, support for using the death penalty is as low as 11\% (Ipsos-MORI 2007). It is particularly interesting to note that support among those with the highest education (over college level) declined from $69 \%$ in 1950 to a mere $14 \%$ in 1980 . Among the group who were most supportive of capital punishment under the Nazis, support sank to $27 \%$ in 1980 . Educational level now worked as a buffer against supporting the death penalty rather than previously, as an incentive towards supporting such practices (Reuband 1980: 542-46, 550). The German example has shown how easily public opinion adapts to more liberal practices when informed by arguments about the inhuman and ineffective consequences of the death penalty. In France, we have seen a similar development. When François Mitterand abolished the death penalty in France in the early 1980s, a majority of $63 \%$ still supported the death penalty. Now that it has been banned from use in the European Union, French opinion has turned significantly more lenient even if support is still as high as $45 \%$, with only $14 \%$ strongly in favour; $21 \%$ think the death penalty is applicable to the crime of murder (Ipsos-MORI 2007)

The same development could be obtained in China if the regime started propagating what they already know about the ineffectiveness of capital deterrence. In other words, the German experience is clear evidence that the Chinese state could have a very strong educative effect on its own people in general, and on its own elites in particular, if they 
were to change their present extensive use of the death penalty. One important finding of the ICVS gives support to this argument. One of the general conclusions is that public attitudes to punishment seem to reflect and support established sentencing traditions (Mayhew and van Dijk 1997). China, an otherwise educative state, with a strong emphasis on pushing the agenda of “spiritual civilization” (jingshen wenming 精神文明) seems to be too attached to former moral panics and harsh legal sentencing to be able to change their present practices. Although few legal scholars in China today would endorse full abolition, there is presently a will among them to restrain former practices, and to reduce the use of the death penalty as well as harsh and cruel punishment in general (Hu 2000; Chen 2000). "Gradually abolishing the death penalty" has now again been suggested in China (Reuters News 2004).

\section{Scenarios of Future Crime and Punishment}

In a 1982 speech against economic crime, Deng Xiaoping advocated that the "struggle will have to be waged daily for 18 years" to be won before the end of the millennium. Has his deterrence policies been effective? Contrary to the relative percentage of juvenile crime, which has been reduced as a function of the end of the baby-boomers dominating the juvenile age cohorts (Jiang et al. 2002), economic crime and corruption has continued to soar. The international global corruption reports have all indicated that corruption has become more serious in China over the last decade (Guo and Liao 2004). Professor Angang $\mathrm{Hu}$ at Qinghua University has put the present cost of corruption as high as 13-16\% of GDP. He further estimated that $15-20 \%$ of public project funds "leak" into private hands $(\mathrm{Hu}$ 2001: 34, 61). Although we are working with insecure data, there is no doubt that economic crime has become far more serious since Deng started his "daily struggle" in 1982, with its repeated campaigns of harsh sentencing. We have to conclude that harsh punishment is quite an unproductive way to stop crime. For instance, the Chinese drug problem has exploded despite the government's stern policies on drug crime and frequent use of the death penalty for trafficking. China was nearly drug-free in 1980, but had well over 1 million drug addicts by the end of 2003 .

The opportunity structure for increased crime is growing, and instead of more harsh punishment, legal and social reforms would be much more adequate ways to deal with the present problems. The UN has concluded that relative income inequality is perhaps the best indicator of increased crime in any country. The differences between classes as well as between urban and rural areas have increased explosively in China, and the country is moving toward the list of countries with the most unequal income distribution. Data from 1978 indicated a Gini-coefficient as low as 0.18 . Ten years into the reforms it had reached 0.382, and in 1996 it stood at 0.458. A 2001 report gave the figure 0.50. (Ma 2001: 69,79, Ding 2002; China Centre for Economic Research 2002). Despite inaccurate figures, there is little doubt that income inequality has spiralled in China since the start of the reform period. (Bramall 2000; Riskin and Zhao 2001). It should be added that the subjective element of visibility and the conspicuous consumption of the rich probably enhances the problem as people are faced with affluence and inequality in a direct way never before experienced in the People's Republic.

It has further been observed that organized crime is a bigger problem in countries where the judicial system is underdeveloped; this particularly concerns the link between corruption and organized crime (van Dijk 2000). An independent, and thereby more accountable, judiciary, however, still seems too be too radical a reform for the Party-one 
potentially threatening its power. The paradox here is the argument of stability and harmony used by the Party. Instead of stability, holding back legal reforms in this field will probably lead to increased corruption and mounting social unrest, destabilizing the country in the long run.

In conclusion, is China still in a state of times of chaos like in the saying: "In times of chaos, hard measures must be used" (zhi luanshi yong zhongdian 治乱事用重典), and does China still need to justify the harsh punishment regimes through an assumption of chaos? China does not have to be unduly alarmed by their rates of traditional crime, which are still relatively minor in a global sense although they are increasing. China, however, should still be on the alert against the interlinked phenomena of corruption, organized and violent crime. Chaos is not the right way of summing up the situation in China today, and with the increased harmony advocated by $\mathrm{Hu}$ Jintao, the need for "harsh measures" should disappear. My argument and that of the criminological evidence is that hard measures probably destabilize society more than they stabilize it in the long term. The answer for China, however, does not rest on even harsher punishments. The continued emphasis on "harshness" might instead be counterproductive. Today's harshness brutalises the crime scene and makes the problem of crime more serious. A culture of lawfulness rather than one of punitiveness should be implemented. Two alarming trends in China-the growing social inequality and the continued deficit in terms of the rule of law-are most certainly linked to the problems of future crime. The problem of crime can be mended only through legal and social reforms. Popular support for the regime, however, is gained not only by its ability to deliver economic prosperity. Legitimacy also flows from the regime's ability to uphold order, and there is much popular support for tough sentencing.

Thus, reactions against crime in Chinese society might not be limited to the wish to solve the problem of crime as such. The reactions against crime have to be seen in terms of the regime's legitimacy and its alleged defence of the social and moral order in a society undergoing rapid change. In conclusion, both the elements of a merciful past and the emergence of modernity should work in the direction of pushing China towards a position of less harshness in punishment. Chinese culture is so much more than harshness in punishment. There is a repertoire in that culture both of harshness and mercy. The merciful potential in the country's history and culture is yet to be explored in its modern form. I think the trend towards a milder punishment regime is inevitable, and it is important to show that this is not a trend that runs contrary to Chinese culture and sentiment. It is time to revitalise the traditions of mercy to make China into a truly modernised nation.

Open Access This article is distributed under the terms of the Creative Commons Attribution Noncommercial License which permits any noncommercial use, distribution, and reproduction in any medium, provided the original author(s) and source are credited.

\section{References}

Archer, D., \& Gartner, R. (1984). Violence and crime in cross-national perspective. New Haven: Yale University Press.

Ashworth, A. (2000). Sentencing and criminal justice, 3rd edn. London: Butterworths.

Bailey, W. C., \& Peterson, R. D. (1989). Murder and capital punishment: A monthly time-series analysis of execution publicity. American Sociological Review, 54(5), 722-743.

Bakken, B. (2000). The exemplary society. Human improvement, social control, and the dangers of modernity. Oxford: Oxford University Press. 
BBC Monitoring (2002). BBC monitoring asia pacific - political, 25 January 2002.

Bodde, D., \& Morris, C. (1967). Law in Imperial China. Cambridge: Harvard University Press.

Beccaria, C. (1764/1996). Of crimes and punishment (Dei delitti e delle pene). New York: Marsilio.

Benn, C. (2002). Daily life in traditional China - the Tang Dynasty. Westport: Greenwood.

Bourgon, J. (2003). Chinese executions. Visualising their differences with european supplices. European Journal of East Asian Studies, 2(1), 153-184.

Bowers, W. J., \& Pierce, G. (1980). Deterrence or brutalization: What is the effect of executions? Crime and Delinquency, 26, 453-484.

Bramall, C. (2000). The quality of China's household income surveys. The China Quarterly, 167, 689-705.

Chen, X. (2003). In X. Chen (Ed.), Zhongguo sixing jiantao: yi qiangxia liuren an wei shijiao (An examination of the death penalty in China from the point of view of the hold the execution case), Beijing, Zhongguo jiancha chubanshe.

Chen, Y. (2000). Fan kuxing. Dangdai Zhongguo de fazhi he renquan baohu (Against torture. Legal policy and human rights protection in today's China), Beijing.

China Center for Economic Research (2002). Beijing University in an invitation document for the international symposium, Equity and social justice in transitional China, Beijing, July 11-12, 2002.

Cochran, J. K., Chamlin, M. B., Seth, M. (1994). Deterrence or brutalization - an impact assessment of Oklahoma's return to capital punishment. Criminology, 1(32), 107-134.

Cochran, J. K., \& Chamlin, M. B. (2000). Deterrence and brutalization: the dual effect of executions, Justice Quarterly, 17(4), 685-706.

Deng, X. (1984). Combat economic crime, Speech held April 10, 1982, Selected works of deng xiaoping 1975-1982 (pp. 380-82). Beijing: Foreign Languages Press.

Deng, X. (1987). Fundamental issues in present-day China. Talk at the meeting of a standing committee of the political bureau of the central committee, 17 January 1986 (p. 137). Beijing: Foreign Languages Press.

Ding, X. L. (2002). From big social problems to explosive political troubles? - the challenges of managing a huge society under rapid transformation at a politically difficult time. In J. Wong \& Y.-n. Zheng, (Eds.), China's post-jiang leadership: Challenges and adaptation. Singapore: Singapore University Press.

Douglas, M. (1966). Purity and danger: An analysis of concepts of pollution and taboo. London: Routledge and Keegan Paul.

Durkheim, É. (1983). Durkheim and the law. In S. Lukes \& A. Scull (eds) Oxford: Robertson.

Elias, N. (1994). The civilizing process. Oxford: Blackwell.

Feng, S. (2001). Crime and crime control in a changing China. In J. Liu, L. Zhang \& S. F. Messner (Eds.), Crime and social control in a changing China. Westport: Greenwood.

Gao, M. (2004). Lüetan wo guo de sixing lifa jiqi fazhi qushi (On Chinese legislation concerning the death penalty). in Zhao Bingzhi, "Zhongguo feizhi sixing zhi lu tansuo" (The road of the abolition of the death penalty in China, pp. 15-20, 23-30). Beijing, Renmin gongan daxue chubanshe (People's Public Security University Press).

Guo, Y., \& Liao, R. (2004). Transparency international, Global corruption report 2004, Country report. China. http://www.globalcorruptionreport.org.

Hu, Y. (2000). Cun yu fei. Sixing jiben lilun yanjiu (Revision or abolishment. A general theoretical study of the death penalty, pp. 341-46). Zhongguo jiancha chubanshe, Beijing.

Hu, A. (2001). Fubai: Zhongguo zui da de shehui wuran (Corruption: China's largest social polluter). In Zhongguo: Tiaozhan fubai (China: Fighting against Corruption) (Ed.). Zhejiang renmin chubanshe, Hangzhou.

Ipsos-MORI (2007). Death Penalty - International Poll, http://www.ipsos-mori.com/researchpublications/ researcharchive/poll.aspx?oItemId=163, accessed 10 March, 2010.

Jiang, L., Xueyi, L., \& Shan, T. (Eds.). (2002). Zhongguo: shehui xingshi fenxi yu yuce: (Analysis and forecast of the social situation in China). Zhongguo shehui kexueyuan chubanshe, Beijing.

Johnson, E. A., \& Monkkonen, E. H. (1996). The civilization of crime. Urbana and Chicago: University of Illinois Press.

Kataoka, M. (2004). Field Poll. State support remains strong for death penalty, The Press Enterprise, 5 March, p. A01. Factiva doc. no. RVSD000020040306e03500011.

Kobler, A. (1980). Police homicide in a Democracy. In R. Lundman (Ed.), Police Behaviour. New York: Oxford University Press.

Leng, C.-C. (1967). Justice in Communist China. New York: Oceana Publications.

Liang, G. (2004). Gongzhong rentong. zhengzhi jueze yu sixing kongzhi (Public identity, political choice, and control of the death penalty), Faxue yanjiu, No., 4, 15-27.

Lim, B. K. (2004). China's security tsar orders fewer executions, Reuters News, March 9, Beijing. 
Ma, G. (2001). Population migration and crime in Beijing, China. In J. Liu, L. Zhang, \& S. F. Messner (Eds.), Crime and social control in a changing China (pp. 65-73). Westport: Greenwood Press.

Madsen, R. (1990). The politics of revenge in rural China during the cultural revolution. In: J. N. Lipman \& S. Harrell, Violence in China. Essays in culture and counterculture (pp. 175-198). New York: State University of New York Press.

Mao, Z. (1927/1967). Report on an investigation of the peasant movement in Hunan, selected works of Mao Zedong, Vol.1 (pp. 23-59). Beijing, Foreign Languages Press.

Mao, Z. (1977). Strike surely, accurately and relentlessly in suppressing counter-revolutionaries, selected works of Mao Zedong, Vol. 5, (pp. 53-56), Beijing: Foreign Languages Press.

Mayhew, P., \& van Dijk, J. J. M. (1997). Criminal victimisation in eleven industrialized countries: Key findings from the 1996 International Crime Victimisation Surveys. London: Home Office Publications.

Mayhew, P., \& van Kesteren, J. (2003). Cross national attitudes to punishment. In J. Roberts \& M. Hough (Eds.), Changing public views of punishment. Cullompton: Willan Publishing.

McKnight, B. E. (1981). The quality of mercy-Amnesties and traditional Chinese justice. Honolulu: University Press of Hawaii.

Mühlhahn, K. (2009). Criminal justice in China, A History. Cambridge: Harvard University Press.

Newman, G. (Ed.). (1999). United nations global report on crime and justice, United Nations Office for Drug Control and Crime Prevention. Centre for International Crime Prevention. New York: Oxford University Press.

Phillips, D. P. (1980). The deterrent effect of capital punishment: new evidence on an old controversy. American Journal of Sociology, 86, 139-148.

Reuband, K.-H. (1980). Sanktionsverlangen im Wandel. Die Einstellung zur Todesstrafe in der Bundesrepublik Deutschland seit 1950 ( Changes in sanctioning. Death penalty in the Federal Republic of Germany since 1950). Kölner Zeitschrift für Soziologie und Sozialpsychologie, 32, 535-558.

Reuters News (2004). China law experts advise less use of death penalty, 10 August, Factiva doc. no. LBA0000020040810e08a005hg, accessed 15 September 2004.

Riskin, C., Zhao, R. \& She, L. (Eds.) (2001). China's retreat from equality, income distribution and economic transition. Armonk: Sharpe.

Roberts, J. V., Stalans, L. J., Indermaur, D., Hough, M. (2003). Penal populism and public opinion. Lessons from five countries. Oxford: Oxford University Press.

Scobell, A. (1990). The death penalty in Post-Mao China, The China Quarterly, No.123, September, pp. $503-520$

Shepherd, J. M. (2005). Deterrence versus brutalization: capital punishment's different impacts among States. Michigan Law Review, 104(2), 203-256.

Spierenburg, P. (1966). The spectacle of suffering: Executions and the evolution of repression: from a preindustrial metropolis to the European experience. Cambridge: Cambridge University Press.

Stack, S. (1987). Publicized execution and homicide 1950-1980. American Sociological Review, 52, 532540.

Stalans, L. J., Indermaur, D., Hough, M., Roberts, J. V. (Eds.). (2003). Penal populism and public opinion: Lessons from five countries. Oxford: Oxford University Press.

Survey of World Broadcast (1991-1992). (SWB-FE) Nos. SWB-FE/1353,11 April 1992, p. B2/4.

Sutherland, E. D., Cressey, D. R., Luckenbill, D. F. (1992). Principles of criminology (11th Edn.). New York: Rowman and Littlefield.

Tanner, H. M. (1999). Strike Hard! Anti-Crime campaigns and Chinese criminal justice, 1979-1985. Ithaca: Cornell East Asia Series.

Trevaskes, S. (2007). Courts and criminal justice in contemporary China. Lanham: Rowman and Littlefield.

Van Dijk, J. J. M. (2000). Does crime pay? On the relationships between crime, rule of Law and Economic Growth. Forum on Crime and Society, 1(1), 1-16. February.

Whitman, J. Q. (2003). Harsh justice. Criminal punishment and the widening divide between America and Europe. New York: Oxford University Press.

$\mathrm{Xu}, \mathrm{Q}$. (1988). Hubei Jingzhou diqu nongcun tuliuzi fanzui diaocha (An investigation of crime among local thugs in Hubeis Jingzhou area, in Zhongguo qingshaonian fanzui yanjiu nianjian 1987. Chunqiu chubanshe: Beijing.

Zhao, B. (2004). Cong Zhongguo sixing chengce kan fei moli fanzui sixing de zhubu feizhi wenti (On the Chinese policy of gradual abolishment of the death penalty for non violent crimes). in Zhao Bingzhi, "Zhongguo feizhi sixing zhi lu tansuo" (The Road of the Abolition of the Death Penalty in China, pp. 1114, 18-22), Beijing, Renmin gongan daxue chubanshe (People's Public Security University Press).

Zhao, B. (2007). Sixing gaige yanjiu baogao (Report on the reform of the death penalty). Beijing: Falü chubanshe . 
Zhao, G. (2006). Guanyu woguo xiongsha fanzui de yige jichu fenxi (A basic analysis of homicide in China). Lilun qianyuan, No., 13, 18-20.

Zhao, Z. (2005). You xianzhi dao feizhi: sixing lujing jiqi jueze (From restriction to abolishment: choices and approaches for the death penalty), in , Chen Zexian, Sixing - Zhongwai meizhu de jiaodian (Death penalty - The global focus), Beijing, Zhongguo gong'an daxue chubanshe, pp. 221-236

Zhonghua renmin gongheguo gonganbu (Ed.) (1992). (The PRC Ministry of Public Security, ed.) Nin ganjue anquan ma? (Do you feel safe?), Beijing, Qunzhong chubanshe.

Zhou, D., Sun, D., Zhang, S. (1981). Yi fa cong zhong cong kuai daji yanzhong de xingshi zuifan (Use the law to strike severely and rapidly against serious criminal offenders), Remnin ribao, 25 June 1981, p. 5

Zhu, X. (2003). Zuiguo yu chengfa (Offence and punishment). Tianjin guji chubanshe: Tianjin. 